\title{
O PRAGMATISMO DE NIETZSCHE E O SEU DESDOBRAMENTO ESTÉTICO SEGUNDO HABERMAS
}

\author{
José Nicolao JULIÃO ${ }^{1}$
}

\section{Um tributo a Oswaldo Giacoia}

- RESUMO: Este artigo tem como pretensão reconstituir o argumento da interpretação crítica de Habermas sobre a filosofia nietzschiana, focando, sobretudo, o posfácio, escrito em 1968, a uma coletânea de textos de Nietzsche sobre teoria do conhecimento. A minha intenção é apresentar a gênese da interpretação, dezessete anos mais tarde, em o Discurso Filosófico da Modernidade, (1985), onde Nietzsche é apontado, por Habermas, como sendo o ponto de inflexão (Drehscheibe) da modernidade, que gerou, dessa forma, "um discurso irracional, metafisicamente desfigurado", base da pós-modernidade. Porém, como o posfácio é contemporâneo da obra Conhecimento e Interesse, (1968), na qual há um capítulo dedicado a Nietzsche que, em muito o complementa, resolvi utilizar este material com o objetivo de me auxiliar nesta interpretação.

- PALAVRAS-CHAVE: Conhecimento, modernidade, pós-modernidade, interpretação.

\section{Introdução}

Os efeitos da provocação de Nietzsche sobre Habermas aparecem em dois momentos distintos da produção intelectual do filósofo de Frankfurt, que, geralmente, tem a obra dividida em três fases. ${ }^{2} \mathrm{O}$ escrito que me pro-

1 Professor Adjunto da Universidade Federal Rural do Rio de Janeiro. Artigo recebido em 03/08 e aprovado em 05/08.

2 Primeiro, numa perspectiva epistemológica, o traço comum desses trabalhos é a crítica ao positivismo; segundo, numa perspectiva político-cultural, a crítica ao Estado e à sociedade é o fio condutor desses trabalhos; e em terceiro, numa teoria da competência comunicativa, a característica desses trabalhos é a elaboração da teoria do agir comunicativo. Porém, todas as fases estão integradas, procurando elucidar a relação entre a teoria e a prática (cf. Freitag; Rouanet, 1980). 
ponho a analisar aqui, está inserido na primeira fase da obra, trata-se de um posfácio a uma coletânea de textos de Nietzsche sobre teoria do conhecimento, publicado em 1968, e é contemporâneo da elaboração de Conhecimento e Interesse (CI), também, de 1968, em que é dedicada uma passagem a Nietzsche com o título: "A redução dos interesses do conhecimento em Nietzsche". Nessa fase aparece a primeira provocação.

O segundo efeito da provocação surge em O Discurso Filosófico da Modernidade (DFM) de 1985, na terceira e derradeira fase da obra de Habermas, na passagem: "A entrada na modernidade: Nietzsche como ponto de inflexão (Drehscheibe)". Entre esse último texto e os dois primeiros há uma distância de dezessete anos. Porém, o que mais chama a atenção do leitor é que na primeira fase da investigação, Habermas anunciara que "Nietzsche perdeu por completo sua capacidade de contágio" (Habermas, 1968a, p.237) e, depois, em DFM, situa-o como sendo o ponto de entrada na pós-modernidade. Todavia, não perde o seu tom crítico em relação ao "Filósofo do Martelo". A crítica nietzschiana à grande tradição filosófica - tanto teórica quanto moral -, sobretudo, à racionalista, soa como um argumento do tipo cético e, por isso, deve ser superado, pois oferece um grande perigo ao projeto da Aufklärung do qual Habermas, em nosso tempo, é o seu mais eminente representante e herdeiro. Em o DFM, Nietzsche é tratado como um desvio da modernidade e por ter rejeitado a razão, como sendo um instrumento de preservação do conteúdo emancipatório, acabou lançando-se para o "irracional metafisicamente desfigurado". (Habermas, 1985, p.117).

\section{Crítica ao pragmatismo - os estudos dos anos 60}

Nos textos da primeira fase, ainda fortemente influenciado pela teoria crítica, Habermas faz uma contundente crítica à crítica de Nietzsche, à tradição da teoria do conhecimento, por ter ele negligenciado a relação entre conhecimento e interesse e só ter visto por trás de todo o conhecimento um interesse de teor niilista. Para ele, "Nietzsche percebeu a íntima relação entre conhecimento e interesse, porém, psicologizou-a, estatuindo-a como elemento básico de uma dissolução metafísica do próprio conhecimento" (Habermas, 1968b, p.353), sem ter, portanto, estabelecido um valor positivo a essa relação. Segundo Habermas, ao contrário de Nietzsche, o conhecimento deve ser movido por um interesse, todavia, esse deve ter um cunho emancipatório e nunca niilista, desagregador ou de alienação (Entfremdung).

O posfácio, apesar de estar inserido no contexto dessa última problemática supra citada, tem uma certa peculiaridade, pois, além de se tratar de um posfácio a textos de Nietzsche sobre teoria do conhecimento, tem, também, um aspecto expositivo didático, no qual Habermas procura de- 
monstrar de forma crítica a posição nietzschiana em relação ao conhecimento sem relacionar com outras teorias como faz em CI.

O posfácio começa com a seguinte afirmação, que já mencionei, em parte, anteriormente:

A obra de Nietzsche exerceu no período entre guerras, sobretudo, na Alemanha, uma particular fascinação. O pathos de seus juízos e pré-conceitos, as energéticas fórmulas de sua filosofia da decadência e a sedutora afirmativa dos "afetos que dizem sim", determinaram o estilo mental e os problemas de toda uma geração de intelectuais pseudo-radicais, descontentes com a tradição ocidental. Cabeças tão heterogêneas como Oswaldo Spengler, Carl Schimitt, Gottfried Benn, Ernest Jünger, Martin Heidegger e também Arnold Gehlen mostram afinidades nesta paixão; são exemplos de um afeto que deriva melhor da expressão do pensamento do que da forma de argumentação. Nietzsche configurou e reforçou então uma mentalidade que de modo algum se limitou aos "revolucionários de direita". Mas, tudo isso jaz hoje atrás de nós e nos é quase incompreensível. Nietzsche perdeu por completo sua capacidade de contágio. (Habermas, 1968a, p.237)

Essa afirmativa, de certo modo, foi um pouco precipitada, pois estávamos nos idos dos anos 60, do séc. passado, período do grande boom do nietzschianismo na França; no início da elaboração da edição crítica das obras completas de Nietzsche, por Colli e Montinari; antes da criação dos Nietzsche Studien e, mais ainda, como afirma Josef Früchtl, "Habermas não percebeu a provocação que Nietzsche exercia sobre ele, que fez com que em DFM, situasse-o como o centro de entrada na modernidade". (Früchtl, 1990, p.431-461).

Não obstante, Habermas continua a sua argumentação, situando uma determinada discussão acerca da concepção de mundo (Weltanschauung) de Nietzsche, centrada nos temas: do niilismo, da vontade de poder e do eterno retorno do mesmo. Segundo ele, nos anos 20 e no início dos anos 30 a influência literária de Nietzsche veio acompanhada de uma discussão filosófica: "Os três elementos centrais de sua doutrina... foram reconstruídos como tese de um escritor filosófico e investigados em sua conexão mútua" (Habermas, 1968a, p.237). Por mais heterogêneos que sejam os pontos de vista desses autores mencionados por Habermas, segundo ele, há algo em comum entre eles, pois seguem as dimensões temáticas eleitas pelo próprio Nietzsche. Essas discussões seguem o impulso que surgiu da ruptura com a tradição filosófica no meio do séc. XIX e que, em Nietzsche, se desenvolveu sob o rótulo do niilismo.

Para Habermas, os estilos aforismáticos e assistemáticos de Nietzsche contribuiram, em muito, para uma total liberdade na interpretação de sua obra e de seus principais temas que, muitas vezes, serviam de pano de fundo para os intérpretes exporem os seus próprios pensamentos. Entre esses, 
são citados: Klages (As Conquistas Psicológicas de Nietzsche - 1924); Bäumler (Nietzsche, o Filósofo e o Político - 1931); Jaspers (Nietzsche - Introdução à Compreensão de sua Filosofia - 1936); Heidegger ("A frase de Nietzsche "Deus está morto'" - 1950) 3 e K. Löwith (A Filosofia de Nietzsche do Eterno Retorno do Mesmo - 1934), todos no ambiente alemão. Depois da guerra, esses trabalhos exerceram forte influência na América e na Hungria, tendo como seus principais representantes W. Kaufmann (Nietzsche Filósofo, Psicólogo, Anticristo - 1950), e Luckács (A Ruína da Razão - 1955). Com total indiferença, Habermas não cita nenhum trabalho de autor de língua francesa que, na época, já era de grande importância. ${ }^{4} \mathrm{E}$, segundo ele, o próprio Nietzsche tentou dar uma orientação de seu pensamento através de sua teoria da vontade de poder e da hipótese do eterno retorno do mesmo. Essas doutrinas foram o centro da discussão que se travou em torno da sua filosofia. Dessas discussões, delinearam-se pelo menos quatro hipóteses. ${ }^{5}$ As duas primeiras são simples e estão imbricadas, segundo elas: ou bem uma das duas teses é deixada de lado em favor da outra, ou bem são as duas deformadas de tal modo que as suas conciliações deixam de ser problemáticas. As outras duas teses tentam estabelecer uma ordem serial entre as hipóteses, de cunho tanto lógico quanto histórico-psicológico: por um lado, concebe-se a hipótese do eterno retorno como a doutrina propriamente afirmativa de Nietzsche e a vontade de poder como a reflexão que, na consciência moderna, constata a situação niilista que nos encontramos e supera a si mesma em favor de uma concepção antiga do mundo; por outro lado, a esta proposta de interpretação opõe-se frontalmente uma outra,

3 Apesar desse artigo só ter sido publicado em 1950 em Holzwege, ele já havia sido redigido no que tem de essencial em 1943. Sabe-se, também, que os estudos de Heidegger sobre Nietzsche são anteriores a essa data, datam de 1936-37.

4 Por ex.: Bataille (Sobre Nietzsche - 1945), Andler (Nietzsche, sua vida e seu pensamento, v.3 1958), Deleuze (Nietzsche e a filosofia - 1962), Granier (O problema da verdade na filosofia de Nietzsche-1966).

5 Trata-se da famosa aporia entre os conceitos nietzschianos, vontade de poder e eterno retorno. Para uma melhor compreensão da questão, cf. K. Löwith, em Nietzsches Philosophie der ewigen Wiederkehr des Gleichen (1934), p.99, é um dos que defendem a hipótese da contradição mútua entre a vontade de poder e o eterno retorno; A. Baeumler, em Nietzsche, der Philosoph und Politiker (1931), também vê uma oposição entre os dois pensamentos principais da filosofia de Nietzsche; E. Fink, em Nietzsches Philosophie (1960), p.173-76, fala de uma unidade incompreensível entre as duas doutrinas, devido às suas contradições. M. Montinari, em Che Cosa Ha Veramente Detto Nietzsche (1975), vê uma incompatibilidade entre os dois pensamentos de Nietzsche, pois, segundo ele, da vontade de poder se pode estabelecer um sistema e do eterno retorno não. Para a defesa da hipótese da compatibilidade entres as duas doutrinas ver: W. Müller-Lauter, Nietzsche, seine Philosophie der Gegensätze und die Gegensätze seiner Philophie (1971), p.135 ss...; M. Heidegger, sobretudo, Nietzsche II, texto publicado em 1961, mas redigido o essencial nos cursos de 1940 a 1946; G. Deleuze, Nietzsche et la Philosophie (1962); G. Abel, Die Dynamikder Willen zur Macht und ewiege Wiederkehr (1984). 
que consiste em interpretar o eterno retorno como um pensamento que tem o valor de nos libertar do fetiche do pensamento teleológico, nos deixando, por isso, inicialmente, em situação de remontarmo-nos além das tradições morais em que, em cada caso vem dogmatizado um particular complexo das condições de vida e, ainda, reconhece a vontade de poder como a condição geral da razão prática.

Habermas se recusa a entrar nessa discussão sobre o estatuto da vontade de poder e do eterno retorno, pois pensa que tais questões não têm mais do que um interesse histórico, isto é, datado, isolado e de erudição supérflua. A meu ver, essa posição de Habermas, ao invés de expressar uma fuga das questões essenciais da filosofia de Nietzsche, ao contrário, parece sugerir uma alternativa às investigações da sua obra, que estão por demais viciadas nessas temáticas e nos dificultam a sua absolvição das malhas da metafísica.

Dando mais relevância ao tema do niilismo e a suas conseqüências teórico-pragmáticas, Habermas afirma que, outra questão são os argumentos formais que operam na base da temática do niilismo, a saber: a crítica à moral que tem como pressuposto geral a perspectiva da interconexão entre a teoria e a práxis vital. Nesse ponto, Habermas parece fazer o que ele acusava em outros autores, "de fazerem de Nietzsche um pano de fundo para exporem o seu próprio pensamento", ou seja, fundamenta uma pragmática a partir de seus próprios pressupostos. Afirma categoricamente: "Nietzsche tem visto que as normas do conhecimento não são independentes das normas da ação, que há uma vinculação imanente entre conhecimento e interesse". (Habermas, 1968a, p.242).

Para Nietzsche, o niilismo é a constatação de que os valores que orientavam as ações e o conhecimento humano, até então, eram desprovidos de sentido. Dessa forma, a pretensão da teoria clássica - de conhecer a essência do mundo e, através dela, orientar o conhecimento e as ações humanas - não passa de uma apelação moral, pois as orientações das ações dependem, tão somente, dos valores que, por sua vez, não necessitam de um nexo teorético. Porém, Nietzsche, como constata Habermas, não se conforma nem com a situação cética que o niilismo possa sugerir, que é a falta de ação mediante a constatação de uma multiplicidade de valores; nem com a posição dogmática decisionista ${ }^{6}$ que é subjetiva e solipsista, em última instância, arbitrária. Nietzsche, então, vai através de uma gênese do niilismo, investigar o valor do valor e a partir dele resgatar o fundamento possível para a orientação do conhecimento e conseqüentemente da ação. Dessa for-

6 Nietzsche não se utiliza dessa categoria para identificar o dogmatismo, é Habermas quem lha empresta, pois tal temática já lhe era de grande interesse desde Theorie und Praxis. Sozialphilosophiche Studien, de 1963, na passagem, "Dogmatismo, Razão e Decisão", p.307-27. Sobre essa questão, cf. MacCarthy, 1978, cap.I. 
ma, são os novos valores - não mais externos à vida, mas, criados na vida que orientarão as ações futuras. Para Habermas, exaltando o caráter pragmático da questão, aí estão os elementos de uma teoria não convencional do conhecimento que merece uma investigação filosófica com intenção sistemática e, por isso, é necessário se recolocar a questão como centro de discussão. Para demonstrar tal intuito - tudo nos parece - Habermas se apóia em dois escritos de importância esclarecedora sobre a teoria do conhecimento pragmática de Nietzsche: o primeiro, um artigo de Alfred Schmidt, "O problema da dialética na teoria do conhecimento de Nietzsche" - 1963; o segundo, o livro de Arthur C. Danto, Nietzsche como Filósofo - 1965. O primeiro desses escritos tece relações entre Nietzsche e Marx; o segundo tece relações entre Nietzsche e o segundo Wittgenstein. ${ }^{7}$

A idéia de Nietzsche, segundo o filósofo frankfurtiano, é a de voltar a obter, por meio de uma reflexão sobre o niilismo, um terreno a partir do qual seja possível um conhecimento que vincule a orientação à ação, pois nem a metafísica e nem a ciência podem mais oferecer tal nexo. A partir disso, ele analisa a posição ambígua de Nietzsche frente à ciência, que se serve dela para a superação da teoria clássica - a metafísica - pois, em sua pretensão de conhecer o mundo e, por meio desse, orientar os homens em suas ações não foi capaz de se sustentar com o embate das ciências modernas. Todavia, as ciências não foram capazes de criar um novo nexo entre a teoria e a práxis da vida.

No texto de CI que esclarece em muitos aspectos o posfácio, Habermas em continuidade sentencia: "Nietzsche compartilha com o positivismo o conceito de ciência... com cada etapa do progresso científico as concepções arcaicas de mundo, as percepções religiosas e as interpretações filosóficas perdem terreno" (Habermas, 1968b, p.354).

E continua, "Igual a Comte, anteriormente, Nietzsche compreende as conseqüências críticas do progresso técnico-científico como superação da metafísica" (idem, p.355). Todavia, essa não é a posição final de Nietzsche frente à ciência, pois depois de elogiá-la, ele a critica duramente, devido a sua impossibilidade de criar um nexo vital entre a teoria e a prática. Habermas, ainda em CI, para situar a posição crítica, utiliza-se de um aforismo póstumo o qual volta a retomá-lo no posfácio.

7 Para Habermas, desde os prematuros trabalhos de Rudolf Eisler (Teoria do Conhecimento e Metafísica em Nietzsche - 1902), e de Hans Vaihinger (Nietzsche como Filósofo - 1902, 4. Ed. 1916), a teoria do conhecimento de Nietzsche até então não tinha sido levada tão a sério, é bom ressaltar que esses autores desfrutavam de prestígio em seu tempo, pois eram kantianos de grande reputação, fundadores do Kant-Studien, ambos faziam parte do grupo de amigos do Arquivo de Nietzsche em Weimar. Além desses, Habermas, ainda, faz uma exceção aos trabalhos de H. Barth (Ideologia e Utopia - 1961) e Michael Landmann (Espírito e Vida, Varia Nietzschiana - 1951). 
A ciência sonda o curso da natureza, mas jamais pode dar ordens ao homem. O que denominamos de inclinação, amor, prazer, exaltação e esmorecimento, isso tudo a ciência desconhece. Aquilo que o homem vive e vivencia, isto ele precisa interpretar a partir de algo disponível e (assim) apreender e escolher. (Nietzsche, 1962, p.343, v.III $)^{8}$

Acentuando ainda mais o aspecto crítico, afirma:

O processo de esclarecimento, possibilitado pelas ciências é crítico; mas a remoção crítica dos dogmas não liberta, mas deixa indiferente: ela não é emancipatória, mas niilista. (Habermas, 1968b, p.355)

Evidencia-se, com isso, a posição crítica de Nietzsche tanto à tradição da grande filosofia quanto à ciência moderna o que possibilita Habermas a afirmar sobre ele, que é crítico do conceito contemplativo de conhecimento e do conceito de verdade como correspondência que embasam ambos saberes. Para Nietzsche, comenta Habermas, as antigas ontologias tinham a favor delas o nexo entre a teoria e a práxis, porém, esse nexo era sustentado por valores externos à vida. O embate da ciência moderna desmascarou esses valores externos, liberando a humanidade dos preconceitos metafísicos; todavia, não foi capaz de criar um novo nexo entre a teoria e a práxis da vida, deixando a humanidade, assim, ainda presa a um estado (Zustand) niilista.

É a partir deste prisma, que Habermas analisa a posição crítica de Nietzsche frente ao modelo histórico. Na década de 30 do séc. XIX, já se desenvolvia uma cultura histórica orgulhosa de seu caráter científico Elevada ao estatuto de ciência na época, ${ }^{9}$ a história pretendia alcançar a positividade através da inteligibilidade dos fatos, excluindo de sua fundamentação as contingências que impedem o rigor e a objetividade científica. Com o segundo ensaio de suas Considerações Intempestivas (CI), intitulado As Vantagens e Desvantagem da História para Vida (1874), que se constitui como um dos primeiros e mais importantes escritos anti-historicistas, ${ }^{10}$ Nietzsche lança uma crítica bastante corrosiva à cultura histórica que, segundo ele, eliminava do homem a ação, confinando-o no passado, semelhante a um an-

8 Habermas, nos textos dos anos 60, utiliza a edição de Schlechta da obra de Nietzsche - Werke in 3 Bänden, 3 ed. München, 1962.

9 A ciência histórica, na época de Nietzsche, não só ganhou estatuto científico, mas também prestígio político. Schnäderbach, em nota (cf. nota 1), chama atenção para o fato de Leopold Von Ranke ter sido chamado tanto à Berlim (por Friedrich Wilhelm IV) quanto à Baviera (por Maximiliano II) para dar-lhes assessoria política (cf. Schnädelbach, 1991, p.48). Logo Ranke, compatriota de Nietzsche, da Turíngia, a quem o filósofo via com desprezo e ironia, como, p.ex., em Ecce Homo, "Por que sou tão sagaz", 9 (cf. Nietzsche, 1988, p.295, v.VI).

10 Na visão de Schnädelbach o ensaio de Nietzsche, As Vantagens e Desvantagens da História para Vida, constitui-se como o primeiro documento crítico ao Historicismo (cf. Schnädelbach, 1991, p.81). Mas, também Nietzsche faz uma referência a isso em Ecce Homo, "Por que escrevo tão bons livros", "as intempestivas", 1: "Neste ensaio, 'o sentido histórico' de que o presente século se orgulha, é pela primeira vez, reconhecido como doença, como típico sinal de decadência" (Nietzsche, 1988, p.316, v.VI) 
tiquário em posse de um objeto valioso, impedindo-o tanto de um presente autêntico quanto de uma esperança de futuro. Dessa forma, para Nietzsche, enquanto a história obedecer aos critérios do método científico, ficará alienada do complexo da vida.

Segundo Habermas, tanto Nietzsche quanto os jovens hegelianos acreditavam no poder da história, só que para aquele, como afirma em CI:

A consciência histórica só é útil para a práxis da vida enquanto se apropria da tradição e a continua elaborando sob a perspectiva do presente. A história viva faz com que o passado e o estranho sejam constitutivos de um processo atualizado de formação. A formação histórica constitui o parâmetro de "força plástica", pela qual o homem ou a cultura se torna transparente a si mesmo no momento em que presentifica o passado e o estranho. (Habermas, 1968b, p.357)

No posfácio, em continuidade, sentencia:

Nietzsche impõe à história uma exigência desde fora: a história tem de recuperar o seu significado para a prática da vida despojando a si mesma, ainda pagando um preço de uma possível objetividade, da camisa de força da metodologia científica e deixando de ser ciência estrita. (Habermas, 1968a, p.247)

Deste modo, para Nietzsche, o que caracteriza o século XIX não é a vitória da ciência, senão a vitória do método científico sobre a ciência. Habermas termina a explanação da parte da crítica de Nietzsche ao cientificismo da história, indicando o ensaio Sobre a Verdade e a Mentira em um Sentido Ex-Moral (VM), em que, segundo ele, Nietzsche ensaiou elaborar uma teoria não convencional do conhecimento, pois tentou ter uma autocompreensão da ciência para entender o conhecimento científico a partir da sua conexão inalienável com a prática. Mas, abandonou imediatamente esse caminho, um ano depois, na segunda Intempestiva, substituindo-o pelas exigências das ciências históricas, retornando a ele a partir da segunda metade dos anos $70^{11}$ do século XIX. Em VM e nos trabalhos a partir do final

11 A meu ver, Habermas comete um equívoco, ao afirmar que desde os trabalhos da segunda metade dos anos 70, Nietzsche havia retomado a posição crítica e radical de VM, em relação ao conhecimento: "Aber seit Mitte der siebziger Jahre nimmt Nietzsche diese Kritik wieder auf" (Habermas, 1968a, p.248). O equívoco está no uso que faz da preposição dativa seit que designa: desde, a partir de, desde então. Quando Habermas faz uso de tal preposição, ele não diferencia as fases cronológicas da obra de Nietzsche, e parece sugerir uma certa identidade entre os trabalhos da segunda fase e os da terceira. Apesar de nos trabalhos da segunda fase, sobretudo em Humano, Demasiado Humano $(H D H)$, Nietzsche criticar o conhecimento a partir de uma análise da moral, isso não é suficiente para se comparar ao radicalismo de $V M$ e, muito menos, dos trabalhos da terceira fase, chamada transvaloração. Isso porque, o que caracteriza a segunda fase da filosofia de Nietzsche, além da crítica à moral, é a aproximação com as ciências, que faz com que alguns comentadores chamem essa fase de 'positivista'. Desse modo, me parece que o radicalismo da crítica ao conhecimento e a elaboração da categoria de interpretação, fundamental para o perspectivismo, em VM faz com que esse ensaio se aproxime mais dos trabalhos da época da transvaloração, terceira fase, apesar de não ter ainda "o terreno próprio", o qual Nietzsche menciona no prefácio de Genealogia da Moral. 
dos anos 70, Nietzsche desvela os fundamentos morais do conceito de verdade. Mostra que o conhecimento tem duas funções bastante pragmáticas: por um lado, o intelecto é um meio de auto-afirmação, serve ao falseamento e à dominação da natureza; por outro lado, controla um meio ambiente ameaçador e assegura a conservação da vida. Em ambos os casos apóiam-se o entendimento no instinto criador de metáforas e, portanto na energia fundamental de sentido simbólico; em ambos os casos entram o mundo fictício dos símbolos a serviço da satisfação e das necessidades vitais; em ambos os casos devem se cumprir a adicional condição de que o homem não perceba como tais suas próprias maquinações. Somente a ilusão objetivista de que suas interpretações podem ser basicamente verdadeiras, e suas ficções conhecimentos, conferem ao homem segurança.

Habermas para justificar tal posição - a meu ver, muito idêntica à defendida por Vaihinger, ${ }^{12}$ mencionado por ele mesmo - cita uma passagem de $V M$ :

Só esquecendo esse primitivo mundo de metáforas (...) Só esquecendo-se o homem de si mesmo como sujeito, e precisamente como sujeito criador artisticamente (künstlerich schaffendes Subejkt), vive com certa tranqüilidade, segurança e conseqüência. (Nietzsche, 1988, p.883, v.I)

Desse modo, segundo Habermas, o objetivismo, para Nietzsche, oculta o fato de que a subjetividade criadora de sentidos crie as condições da possível interpretação (Interpretatione) daquilo que temos por realidade (Wirklichkeit); Nietzsche, ao mesmo tempo, que põe essa ilusão a descoberto, dissolve também o conceito de verdade como correspondência no sentido de um convencionalismo lingüístico, pois, para ele, o impulso para a verdade é apenas uma obrigação moral que a humanidade estabeleceu para existir. O estrato elementar de um significado simbólico consiste de imagens que são geradas poeticamente por estímulos externos. Entre a imagem e o estímulo não existe nenhuma relação unívoca de correspondência, mas tão somente a manifestação da subjetividade criadora de sentidos.

Só a fixação convencional de determinadas metáforas proporciona aos produtos da fantasia uma aparência de correspondência e, por conseguinte, de verdade. Ser verdadeiro quer dizer usar as metáforas comuns e, portanto, expressas moralmente segundo uma convenção estabelecida. Essa conven-

12 No apêndice de seu livro de 1911, Die Philosophie des als Ob. System der theoretischen, praktischen und religiösen Fiktionen der Menschheit auf Grund eines idealistischen Positivismus, na passagem, "A vontade de ilusão em Nietzsche", Vaihinger trata exaustivamente do tema da ficção em Nietzsche, mostrando as influências que esse recebeu de Lange (História do Materialismo - 1865), que preconizava a idéia da metafísica como uma forma justificada da poesia. 
ção estabelecida é formada pela linguagem. ${ }^{13} \mathrm{Na}$ gramática da linguagem estão incluídas as regras segundo as quais nós ordenamos categorialmente os conceitos metafóricos.

A partir desses pressupostos, Habermas analisa a distinção feita por Nietzsche entre o "homem racional" - o cientista - e o homem intuitivo - o artista; malgrado a distinção, tanto a arte quanto a ciência forjam as metáforas da linguagem. Porém, o homem racional desenvolve o entendimento a serviço da dominação da natureza, rechaça o mal sem obter a felicidade de suas abstrações; o artista, pelo contrário, é o homem intuitivo que ao dar expressão às suas intuições, não só conjura os perigos, mas experimenta, também, igualmente, "iluminação (Erhellung), entusiasmo (Aufheiterung), redenção (Erlösung)". Habermas, utilizando uma terminologia de Adorno, com base no que foi exposto acima, afirma que Nietzsche, na época de $V M$, exibia uma espécie de dialética negativa que no plano da própria visão científica faz aniquilar as categorias da ciência e se deixa guiar pela intuição, um caminho alternativo à mística.

Segundo Habermas, Nietzsche não fez nenhum uso da possibilidade de justificar sua própria teoria, também, sua teoria do conhecimento, desde o ponto de vista de uma linguagem indireta.

Para o filósofo frankfurtiano, a ciência, na opinião de Nietzsche, não faz mais do que desdobrar o aparato categorial inscrito na linguagem e objetiviza a natureza na dimensão quase transcendental (quasi transzendentalem Rahmen); ${ }^{14}$ assim como a analisa com vistas a seu possível controle técnico. Então, a primeira tarefa de uma teoria do conhecimento é repetir e revisar em termos de uma lógica da linguagem a crítica transcendental kantiana da consciência. Segundo Habermas, em alguns textos póstumos, em Aurora,

13 É do conhecimento de todos que Habermas em Teoria da Ação Comunicativa (1981) marca a sua ruptura com a teoria crítica e isso se dá, sobretudo, devido a mudança de paradigma promulgada no interior dessa obra. A linguagem, depois da investida de Habermas, na filosofia analítica da linguagem, passa a ser o paradigma de sua teoria da ação comunicativa em substituição ao paradigma da consciência da época de sua vinculação com a teoria crítica. Dessa forma, seria um exagero dizer que Nietzsche forneceu a Habermas o paradigma da linguagem, mas é plausível de se afirmar que as suas investigações nietzschianas do final dos anos 60 fizeram, talvez, com que ele refletisse tal possibilidade. Nietzsche, bem antes de Wittigenstein, já havia demostrado o significado da linguagem para o conhecimento.

14 Mais uma vez, Habermas transpõe para Nietzsche suas próprias idéias, o conceito de "quase transcendental" é habermasiano. Ele o utiliza como uma proposta que segue regras universais, que permeia uma verdade universal, o que não significa uma verdade dogmática, mas uma verdade fraca, ou seja, "quase transcendental". Por exemplo, na segunda fase de sua obra, o filósofo frankfurtiano utiliza-se do conceito para estabelecer o consenso, que necessita "de instituições racionais, de regras e formas de comunicação, que não sobrecarreguem moralmente os cidadãos, e sim, elevem em pequenas doses a virtude de se orientar pelo bem comum", esta é uma postura quase transcendental (Habermas, 1993, p.94). 
Humano, Demasiado Humano, Para Além de Bem e Mal e Crepúsculo dos Ídolos, Nietzsche tentou deduzir as categorias por via de uma lógica transcendental da linguagem. pois, para ele, as categorias têm a linguagem como perpétuo advogado. Para Nietzsche - tendo como base VM - o mais velho artigo de fé é o "eu" como identidade. Esta identidade é projetada a todas as coisas com as quais surge pela primeira vez a categoria de coisa, da qual se podem predicar propriedades - pois senão nos considerarmos como uma unidade, jamais teríamos formado o conceito de coisa. Na primitiva forma gramatical da proposição, a relação sujeito-predicado tem derivado de um esquema geral de explicação. De modo análogo se tem fixado como forma gramatical e fictícia distinção entre sujeito ativo e o fazer mesmo. Esta distinção arrasta consigo as categorias de causa e efeito, pois a causalidade é representada segundo o modelo de uma obediência do sujeito agente frente às leis. Nietzsche, também concebe ao esquema perceptivo do tempo e do espaço, as operações de contar e medir, como ficções que adquirimos no exercício da gramática de nossa linguagem, como um a priori necessário de toda interpretação, tanto científica quanto ordinária.

Com base nisso, argumenta Habermas contra, se os pré-juízos da razão, que Kant havia chamado de juízo sintético a priori, têm suas raízes na estrutura da linguagem e, se a identidade do sujeito falante, da qual havia forjado Kant a unidade da consciência transcendental em geral, e o EU constituinte do mundo, é igualmente uma ficção lingüística. Portanto, o aparato categorial não pode seguir chamando-se transcendental no sentido kantiano. Nietzsche, como nos mostra Habermas, inverte a pergunta "como são possíveis os juízos sintéticos a priori?" pela pergunta, "por que é necessária a fé nos juízos sintéticos a priori?". Certamente que aqueles pré-juízos da razão seguem sendo transcendentais no sentido de condições subjetivas inevitáveis de toda interpretação lingüística da realidade. No entanto, de modo algum são transcendentais no sentido de uma validade a priori, ou seja, incondicionada., pois, só dependem da forma contingente de nossa linguagem, e as regras da gramática são como todos os símbolos, produto da poíesis da atividade criadora de sentido. A coação que nos leva a ter por verdadeiro os pré-juízos a priori da razão, não resulta de que sejam "verdadeiros", no sentido transcendental; mas ao contrário, o sentido da "verdade" resulta da função da necessidade que nos leva a tê-lo por verdadeiro. Disso decorre a pergunta de Nietzsche: "por que é necessária fé nos juízos sintéticos a priori?". A resposta de Nietzsche, segundo Habermas, é: porque nessa necessidade lógica se impõe a coação metalógica que exerce sobre nós a história natural, impõe-se a necessidade prática da reprodução da vida. A fé na verdade dos juízos sintéticos a priori vem de estimações valorativas. A categoria de estimação valorativa ou valoração serve, segundo Habermas, como suporte a esse conceito revisado de transcendental, pois 
Nietzsche entende os juízos sintéticos a priori como juízos de valor. As regras transcendentais implicitamente contidas na gramática da linguagem, com as quais constituímos o mundo empírico, Nietzsche as chama de juízos fisiológicos de valor. Habermas considera que essas formulações não são muito cautelosas e justificam uma interpretação naturalista - que coincidem com a crua forma de pragmatismo desenvolvida por F. C. Schiller ${ }^{15}$ (Humanism - 1903) e no ambiente alemão por W. Jerusalém (Para Reforma da Instrução na Propedêutica Filosófica - 1885).

Mais ainda, para Habermas, Nietzsche não ultrapassa a colocação kantiana, senão primeiro a prolonga com a crítica à linguagem, e logo depois, com uma virada peculiar a radicaliza. ${ }^{16}$ A redução das regras transcendentais a juízos de valor, quer somente dizer que as operações constituintes do mundo, do aparato categorial contido na linguagem, têm de ser pensadas como surgidas de condições empíricas. Todavia, esse conceito de empírico já não pode ser pensado sob categorias que, por sua vez, poderiam fazer-se derivar das condições empíricas de conservação e crescimento da espécie que, considerada como sujeito, alcançam expressões nos juízos transcendentais de valor. Este sentido de empírico só pode ser justificado num plano metateórico. Apenas sob uma ressalva análoga, segundo Habermas, poderia Nietzsche, crítico do conhecimento, falar de "necessidade biológica" ou "exigências fisiológicas"; e assim, fazer uso do marco categorial da teoria da evolução. Desse modo, para explicitar a ambigüidade metodológica da linguagem quase biológica, em que busca as condições de gestação do aparato categorial, Nietzsche, para Habermas, teria que ter se situado nessa dimensão da experiência da consciência a que antes, certamente sob pressuposto idealista, havia iniciado Hegel na Fenomenologia do Espírito, 1807. Porém Nietzsche não se entregou a esta auto-reflexão da crítica do conhecimento. Antes, com sua inversão da filosofia transcendental, abandonou o conceito mesmo de verdade e buscou uma saída, no subjetivismo da vontade de poder. Essa, apoiada numa teoria perspectivista dos afetos que deve dissolver a teoria tradicional do conhecimento.

A partir disso, Habermas começa por analisar o perspectivismo dos afetos em Nietzsche, que incide como uma forte crítica sobre a teoria kantiana do conhecimento. Segundo tal crítica, se os pré-juízos da razão são determinados por juízos transcendentais de valor, a verdade dos juízos sintéticos a priori não pode consistir em sua correspondência com certa constituição da realidade, senão pelo fato de que tenha creditado sua eficácia ante a reali-

\footnotetext{
15 Ferdinand Canning Schiller (1864-1937) apesar de ser alemão de nascimento, cedo imigrou para Inglaterra depois para América, lugares onde se fez conhecido.

16 Seria a Drehscheibe, de 17 anos depois em o DFM?
} 
dade, numa prévia conexão de interesse. Dessa redução da verdade à instrumentalidade vital, infere Nietzsche, segundo Habermas, não só a inutilidade do conceito de verdade como correspondência, mas também e, sobretudo, a inutilidade do conceito de verdade como tal. Dessa forma, Nietzsche substitui a verdade dos enunciados pela fé subjetiva dos enunciados. Este argumento, para Habermas, parece, à primeira vista, plausível e tem sido freqüentemente usado contra as formas mais ingênuas de instrumentalismo: a utilidade de um instrumento não guarda nenhuma relação lógica com a validade dos enunciados. Correlativamente, tão pouco se pode passar do factum da realidade de determinadas ficções e disso concluir a verdade das mesmas. Nietzsche, segundo Habermas, não vacila em qualificar aqueles juízos fundamentais de valor que, para Kant eram os juízos sintéticos a priori, como os mais falsos juízos e mais profundos erros, devido a sua absoluta imprescindibilidade fática. Aqui a negação do verdadeiro, naturalmente, é um uso irônico da linguagem, o que imediatamente é impugnado com respeito à validade das categorias é só a pretensão do conceito clássico de verdade. Segundo Habermas, isso não diferencia Nietzsche de Kant, pelo seguinte argumento: pois as condições subjetivas da possível objetividade do conhecimento podem não corresponder a nenhuma estrutura de ente, podem não corresponder a nenhum em si. Mas, para Habermas, Nietzsche dá um passo à frente, pois ele afirma que sob o pressuposto de juízos transcendentais de valor, carece de sentido falar de conhecimento possível e, portanto, de juízos que possam ser objetivamente verdadeiros.

Só podemos dar interpretações cuja validade, referida a uma perspectiva expressa em juízos de valor, é fundamentalmente relativa. Para Nietzsche, então: "o que significa o juízo de valor (ou o valorar)? Remete a algum outro mundo, algum mundo metafísico que esteja situado por detrás ou por debaixo? Em resumo: de onde surge o juízo de valor? Ou ele não surge? Resposta: o juízo moral de valor é uma interpretação, um modo de interpretar. E a interpretação (Auslegung) mesma é um sistema de determinados estados fisiológicos: quem interpreta? - nossos afetos". (Nietzsche, 1962, p.480, v.III). No lugar do conhecimento da natureza fenomênica introduz-se uma aparência perspectivista e, dado que as perspectivas, por sua vez, fundamse em nossos afetos, no lugar da teoria do conhecimento se introduz uma teoria perspectivista dos afetos. Seu princípio supremo é que toda fé, todo ser por verdadeiro é algo necessariamente falso, porque não há um mundo verdadeiro - isso é a consumação do niilismo.

Rejeitando considerar qual é o status da teoria nietzschiana do perspectivismo, Habermas se interessa apenas em saber se tal teoria resulta de alguma maneira da crítica do conhecimento. Como, para ele, por certo não há maneira alguma de ver porque as condições transcendentais, se é que já não podem ser pensadas como inventário válido a priori de um sujeito sepa- 
rado do dever e exclusivamente determinado pela unidade de suas realizações sintéticas, não deveriam ser entendidas de forma idênticas em todo momento como condições subjetivas da possível objetividade do conhecimento. Certamente, para Habermas, devemos abandonar aquela pretensão que Kant tentou salvar por meio da dedução transcendental. E sem esta dedução, não é de fato oportuno expressar na forma de juízos sintéticos a priori, que são absolutamente verdadeiros, o sentido das normas segundo as quais se tem realizado a síntese. Tais juízos, afirma categoricamente Habermas, ao surgirem do interesse - que guia o conhecimento da auto-afirmação (Selbsbehauptung) de um sujeito específico contingente, tem o status de regras originadas subjetivamente, de ficções que poderiam ser imediatamente reduzidas a nossa capacidade peculiar de simbolizar. Nietzsche fala da criação de sentidos, poíesis, fabulação. No entanto, ainda assim, teriam o status de ficção creditados na história da espécie e, pois, precisamente conforme a medida destas ficções, que têm sido sedimentadas na linguagem, é objetivada a realidade desde o ponto de vista de seu controle técni$\mathrm{co}$, de sorte que podem obter-se e acumular-se enunciados empíricos intersubjetivamente válidos, de comprovada utilidade técnica. O sentido do acerto empírico dos enunciados pode ser elucidado por referência à possibilidade de uma tradução em recomendações técnicas. Porém, o êxito das operações que levaram a estas recomendações, não é por isso, idêntico à verdade dos enunciados dos quais deduziram tais recomendações, uma vez estabelecidos determinados fins. As informações só são úteis para a vida, isto é, tecnicamente valoráveis, na medida em que acertam com algo no marco transcendental da possível utilização técnica da realidade objetiva. Todavia, este marco transcendental não pode pretender validade absoluta de um conhecimento no sentido de Kant, pois, o mundo que nós constituímos neste marco é literalmente um projeto típico de nossa espécie, uma perspectiva que depende também da contingência determinante da dotação orgânica do homem e das constantes da natureza que o rodeia.

Dito isso, argumenta Habermas que o próprio Nietzsche fala da exigência com que se impõem as valorações transcendentais as quais são nossos pré-juízos racionais; nessa exigência se manifesta a compulsão da natureza, tanto da natureza objetiva que nos circunda quanto da natureza subjetiva do homem, sob cujas condições fáticas se tem formado os pré-juízos racionais num processo transcendental de aprendizagem que abarca a história da espécie. Esses pré-juízos foram inventados, somente na medida em que possibilitaram encontrar enunciados empiricamente coadunados à realidade. Disso, Habermas conclui o seguinte: que as condições subjetivas da constituição de um mundo de casos idênticos, susceptível de controle técnico, não são puros inventos, nem falsificações, senão os elementos adquiridos num processo de formação coletiva, de um projeto de possível do- 
minação da natureza inerente a nossa espécie e, em decorrência disso, diagnostica em Nietzsche um pragmatismo definido em termos de uma lógica transcendental. Mas, segundo ele, Nietzsche percebeu essas conseqüências e, em decorrência disso, a sua insistência de que o aparato cognitivo humano não foi dirigido para conhecimento.

Para Habermas, um dos motivos da recusa da diferença entre ilusão e conhecimento, por parte de Nietzsche, é de um puro tradicionalismo. Para ele, Nietzsche sempre teve em mente o conceito ontológico de verdade. Medida com essa exigência clássica, as condições subjetivas de objetividade possível anulam, simultaneamente, com o objetivismo tradicional, a possibilidade de proposições ontologicamente verdadeiras. Porém, continua Habermas, o perspectivismo que afirma Nietzsche, não conta com a universalidade da aparência da natureza, senão da aparência perspectivista como tal, deste modo, existe somente interpretação. Segundo Habermas, esse giro irracional, em poucas passagens de sua obra, Nietzsche o levou às últimas conseqüências como filosofia monodológica da vida, que define em um texto póstumo dos anos 80 como "Hipótese de que só existe sujeito, o objeto é só uma espécie de efeito de um sujeito sobre outro". (Nietzsche, 1962, p.535, v.III). Para Habermas, essa posição de Nietzsche é motivada por uma generalização de exigências estéticas fundamentais. Contudo se, busca-se uma razão que seja imanente ao próprio movimento do pensamento filosófico, então essa autonomia substancializadora do interpretar poderia resultar como reação de defesa contra um mal entendido naturalista que, segundo Habermas, Nietzsche alimentou demais; e remete a sua tese de CI, que podemos resumir da seguinte forma: Nietzsche não percebe que, ao fazer uso do recurso das ciências naturais, sobretudo da biologia, para fazer crítica à reflexão, está se apropriando da própria reflexão, constituindo assim um paradoxo. ${ }^{17}$ Para reforçar ainda mais tal tese, afirma: "é possível que Nietzsche percebesse de que a reflexão imediata entre o aparato categorial e a legalidade da reprodução orgânica da vida, e em conseqüência, o freqüente recurso às chamadas exigências filosóficas e necessidades biológicas, tinham que embaraçá-lo nas contradições de uma antropologia darwinista do conhecimento" (Habermas, 1968a, p.259).

Nietzsche, segundo Habermas, não refletiu sobre a tensão entre Kant e Darwin, mas foi muito consciente de que não era possível neutralizar o plano da crítica lógico-transcendental da linguagem saltando simplesmente do plano das investigações empíricas. Dessa dificuldade, poderia ter escapado, se fizesse, por um lado, os juízos de valor derivarem daquele impul-

17 Cf. Habermas, 1968b, p.364. 
so poético fundamental que outrora havia identificado na formação de metáforas, ou seja, fizesse derivarem da projeção de sentidos, da geração de ficção; e pondo ao mesmo tempo este ato criador de interpretação permanente, de perpétuo poetizar, em conexão com o acontecer básico do processo da vida orgânica. Para Habermas, esse processo de interpretar em Nietzsche, eleva-se à categoria de Natura Naturans. Uma tal criação de sentido separada da vontade de poder, é algo absoluto. Nela desaparece a diferença entre um projeto próprio da espécie, que tem de creditar-se em condições contingentes e, as projeções em que as nossas fantasias e sonhos cobram uma forma sempre desejada. Nela, dissipa-se aquela diferença que Nietzsche havia assinalado em seus primeiros escritos de teoria do conhecimento: a diferença entre a produção de esquemas explicativos do mundo, a serviço do domínio da natureza, e a produção de aparência ilusória a serviço da adaptação.

Para Habermas, é sobre a base dessa diferença que Nietzsche pode advertir também a compatibilidade de duas categorias do conhecimento: ciência e reflexão. Se a ciência deixa-se compreender em termos nominalistas, como um processo de conhecimento que depende de que se sobreponha a realidade a um esquema explicativo convencional, de tal modo, que a natureza mostre-se sob o ponto de vista de sua eventual disponibilidade técnica, então as experiências que o sujeito específico realiza com suas próprias produções e projetos poéticos em intercâmbio com a facticidade da natureza são subtraídos à irracionalidade: o processo de configuração que nós recorremos como espécie geradora de ficções, sob as coerções de uma natureza racionalizada, tem uma estrutura que nós não inventamos, mas somos constituídos por ele. Daí que, uma reconstituição desse processo de formação não possa proceder em termos nominalistas mas, tão somente, no sentido de uma experiência fenomenológica como em Hegel, ou seja, a reflexão como uma rememoração que abre desde dentro o texto de nosso próprio passado, rememoração, ante cuja violência crítica se dissolvem as objetivações opacas às intuições.

Para concluir o posfácio, Habermas afirma:

A consumação do niilismo nietzschiano na crítica do conhecimento se deve exclusivamente à força desta reflexão. Porém, Nietzsche não pode percebê-la, e se serve dela sempre para mobilizar todo argumento contra os direitos da mesma reflexão. (Habermas, 1968a, p.261)

Com a afirmativa "de que Nietzsche utiliza-se da reflexão para fazer uma crítica à própria reflexão", Habermas está lançando a filosofia nietzschiana numa contradição que a invalida enquanto discurso coerente. Esse tipo de argumentação é a mais antiga objeção do racionalismo clássico contra o re- 
lativismo cético, segundo o qual, seria auto-refutador. Platão e Aristóteles já se utilizaram desse argumento, para combater a posição gorgiana, disseminada na Grécia antiga, que negava a possibilidade de um conhecimento acerca do ser, devido a sua efemeridade, contingência e pluralidade. Tomar a filosofia de Nietzsche como constituinte de uma contradição pragmática e, por conseguinte, como sendo um irracionalismo a serviço do contra-esclarecimento, é torná-la, realmente, algo anacrônico e não 'contagiante'.

\section{Crítica ao esteticismo - dezessete anos depois}

Todavia, apesar da falta de contágio do pensamento nietzschiano sobre o filósofo frankfurtiano durante os 17 anos que se seguem aos estudos dos anos 60, em 1985, ao publicar DFM, Habermas retorna a Nietzsche. Para ele, Nietzsche teria, na modernidade, saltado através de uma Drehscheibe (disco giratório) para fora dos limites da dialética do esclarecimento, gerando dessa maneira, um outro da razão (Anderen de Vernunft), a transmissão de sua filosofia, no séc. XX, forneceu a base do pensamento pós-moderno, Heidegger, Bataille, Foucault e Derrida - resguardando as diferenças - seriam seus herdeiros intelectuais.

Segundo Habermas, a época moderna se encontra sobre o signo da liberdade subjetiva que tem a sua efetivação tanto na sociedade civil quanto no Estado moderno, tal como mostrara Hegel em seus Princípios da Filosofia do Direito, de 1821. Dessa forma, os herdeiros de Kant, assim como os de Hegel, defensores da dialética do esclarecimento, não questionaram as conquistas da modernidade, pois viram nessa época, no novo tempo (neue Zeit), o momento na história no qual o homem munido da razão, desliga-se de toda sugestão normativa externa a si e torna-se senhor autônomo do seu próprio tempo. Por isso, para Habermas, com a entrada de Nietzsche no discurso filosófico da modernidade, a argumentação muda radicalmente, a época moderna perde a sua posição privilegiada. Nietzsche teve a escolha de submeter mais uma vez a razão, centrada no sujeito, a uma crítica imanente, reformulando-a aos moldes do esclarecimento. Todavia, optou em renunciar uma nova revisão do conceito de razão e se despede (verabschiedet) da dialética do esclarecimento, "entronizando o gosto, 'o sim e não no paladar', como órgão de um conhecimento que está além do verdadeiro e do falso, do bem e do mal" (cf. Habermas, 1985, p.119). Desde a sua obra inaugural, O Nascimento da Tragédia (NT), 1869, Nietzsche utiliza-se do fio condutor da razão histórica, para depois, fincar o pé no mito, o outro da razão. Nessa Primeira empreitada, o jovem filósofo tinha diante de si o projeto wagneriano de uma mitologia renovada (neue Mythologie) esteticamente que, tem como função liberar as forças de integração social, cristalizadas na 
sociedade competitiva, descentralizando, dessa maneira, a consciência moderna, abrindo-a para experiências arcaicas. Também tinha esperanças que Bayreuth irradiasse os efeitos da tragédia dionisíaca. ${ }^{18}$ É por isso, como chama atenção Habermas que Nietzsche celebra Wagner como o "revolucionário da sociedade", pois ambos viam, nessa época, que a arte deveria: adquirir um caráter de instituição pública nas formas de uma mitologia renovada e desencadear as forças de regeneração da totalidade ética do povo. ${ }^{19}$ Mais tarde, Nietzsche reconhece que Wagner ainda permanecia preso à visão cristã do mundo, tal como os românticos.

A idéia de uma nova mitologia, como aponta Habermas, já se encontrava entre filósofos e poetas românticos alemães que a viam como um substituto ao poder unificador da religião e como uma forma de introduzir a poesia como força educadora da humanidade. Schelling, por exemplo, apresenta a nova mitologia, no final do seu Sistema do Idealismo Transcendental, de 1800, como não sendo a invenção de um poeta isolado, mas de uma geração que represente, por assim dizer, um único poeta. Schlegel, na mesma direção, em seu Discurso sobre a Mitologia, do mesmo ano de 1800, dizia faltar à poesia da época um centro, tal como era a mitologia para os antigos, e que os pontos essenciais que a poesia moderna fica aquém da antiga podem ser resumidos nas seguintes palavras: não temos ainda uma mitologia. Porém, estamos próximos de obter uma. ${ }^{20} \mathrm{~A}$ diferença desses pensadores com Hegel é evidente, pois não é a razão especulativa, para eles, que substitui o poder unificador, antes reservado à religião, mas a poesia tão logo esteja publicamente em vigor na forma de uma nova mitologia. Todavia, reservada as diferenças, ambos não conseguem superar o âmbito da dialética do esclarecimento, pois em última instância, é a razão especulativa que se excede mediante o programa de uma nova mitologia. É, nesse contexto, que o messianismo romântico, segundo Habermas, necessita de uma outra figura do pensamento, Dioniso, o deus conspirador do êxtase, da loucura e da metamorfose incessante, passa por uma surpreendente revalorização já entre os primeiros românticos. Hölderlin, talvez o mais radical dos filósofos-poetas alemães, em sua elegia "Pão e Vinho", ${ }^{21}$ sugere um paralelo entre Dioniso, o deus que um dia há de retornar de sua peregrinação, com

18 Cf. Habermas, 1985, p.109.

19 Cf. Habermas, 1985, p.110. Habermas tem como base para tal afirmação o então recente livro de Manfred Frank. Der kommende Gott. Vorlesungen über die neue Mytologie. Frankfurt am Main: Suhrkamp, 1982.

20 Cf. Habermas, 1985, p 110.

21 A cristologia de Hölderlin não é analisada, por seus comentadores, apenas na obra de juventude tal como sugere Habermas, com base em Manfred Frank (cf. nossa nota 18), mas também pode ser remetida aos seus últimos hinos. Sobre essa questão, cf. Courtine, 2006, p.113-42. 
Cristo que também um dia - na visão cristã - retornará. A radicalização de Nietzsche, para Habermas, está em não aceitar as posições messiânicas do romantismo, pois essas identificavam o vertiginoso deus do vinho com o salvador cristão, propondo, assim um rejuvenescimento (Vejüngung), não uma despedida (Verabschiedung) do Ocidente. Para Nietzsche, não há espaço para o crucificado na sabedoria trágico-dionisíaca, "Dioniso contra o crucificado" (Nietzsche, 1988, p.374, v.VI).

Nietzsche distancia-se do uso romântico dessas idéias e proclama uma versão mais radical de sua filosofia dionisíaca. Em 1886, no prefácio tardio ao NT, como enfatiza Habermas, ele apresenta as razões filosóficas que o levaram a se afastar do mundo da ópera wagneriana, indagando: "Como deveria ser composta uma música que não tivesse mais uma origem romântica, igual à alemã -, senão dionisíaca?" (Nietzsche, 1988, p 20, v.I). O que diferenciaria o dionisíaco de Nietzsche dos românticos? Para Habermas, Nietzsche não é tão original em sua consideração dionisíaca da história, ele apenas radicalizou a posição dos românticos que após a queda da unidade a qual a religião garantia viam no mito, como os gregos, a unidade com o todo. O que Nietzsche denomina de fenômeno estético, manifesta-se no relacionamento concentrado que mantém consigo mesmo uma objetividade descentrada e liberada das convenções cotidianas da percepção e da ação. Nietzsche, para Habermas, prossegue a purificação romântica do fenômeno estético em relação todo acréscimo teórico e moral. Influenciado por Schopenhauer, ${ }^{22}$ vê na experiência estética, a realidade dionisíaca ser isolada por um abismo do esquecimento contra o mundo do conhecimento teórico e da ação moral, contra o cotidiano. Por isso, a arte permite o acesso ao dionisíaco somente ao preço do êxtase, ao preço da desdiferenciação dolorosa, da perda dos limites do indivíduo, da fusão com a natureza amorfa, tanto interior quanto exterior (cf. Habermas, 1985, p.117). Essa versão schopenhauriana do princípio dionisíaco, segundo Habermas, dá ao programa da nova mitologia uma guinada, alheia ao messianismo romântico, pois trata-se agora de um abandono da modernidade esvaziada pelo niilismo. Com isso, Habermas, mais uma vez, como nos estudos dos anos 60, é implacável contra Nietzsche, devido a sua filosofia apresentar riscos ao programa iluminista o qual o filósofo frankfurtiano se vê vinculado. Afirma ele: "Com Nietzsche, a crítica da modernidade renuncia, pela primeira vez, a reter o seu conteúdo emancipatório. A Razão centrada no sujeito é confrontada com o absolutamente outro da razão" (idem, ibidem). Lançando a filosofia de Nietzsche na irracionalidade metafisicamente desfigurada.

22 Habermas apóia a sua argumentação nesse ponto na passagem do Nascimento da Tragédia, onde Nietzsche com base no principium de individuationis de Schopenhauer fundamenta o estado dionisíaco como um esquecimento de si mesmo (cf. Nietzsche, 1988, p.28, v.I). 
Com a elaboração da doutrina da vontade de poder, no início dos anos 80 , segundo Habermas, ${ }^{23}$ Nietzsche a apresenta como uma versão metafísica do princípio dionisíaco, ela está presente em todo acontecer e explica como surgem as ficções do mundo. O mundo aparece como um tecido de dissimulações e interpretações, as quais não subjazem nenhuma intenção e nenhum texto, a potência criadora de sentidos constitui, juntamente com a sensibilidade que se deixa afetar das maneiras mais variadas possíveis, o núcleo estético da vontade de poder. Por isso, Habermas vê a compreensão de Nietzsche da modernidade desenvolvida em termos de uma teoria do poder, uma crítica da razão desmascaradora que, coloca-se a si mesma fora dos limites da razão. Todavia, essa crítica dispõe de uma certa sugestividade, pois apela, implicitamente, a critérios tomados das experiências básicas da modernidade estética e não reconhece a faculdade crítica de valoração, aguçada no relacionamento com a arte moderna, como um momento da razão. Dessa maneira, a teoria do poder não pode satisfazer a pretensão de objetividade científica e ao mesmo tempo, realizar o programa de uma crítica total da razão. Em decorrência disso, a filosofia de Nietzsche oscila entre duas estratégias: por um lado, sugere a possibilidade de uma observação artística do mundo levada a cabo por meios científicos, porém numa atitude antimetafísica, anti-romântica, pessimista cética. Uma ciência da história dessa espécie, por estar a serviço da vontade de poder, poderia escapar da ilusória fé na verdade. Todavia teria de pressupor a verdade dessa mesma filosofia. Por outro lado, afirma a possibilidade de uma crítica da metafísica que desenterre as raízes do pensamento metafísico, mas sem renunciar de ser ele mesmo uma filosofia. Para Habermas a crítica nietzschiana nessas duas sugestões teria respectivamente, Bataille, Lacan e Foucault, um lado como seus sucessores, Heidegger e Derrida. Ambas sugestões caem no mesmo dilema da filosofia de Nietzsche, pois não conseguem satisfazer ao mesmo tempo as exigências da objetividade científica e, cumprir o programa total da razão, caindo, assim numa auto-refutação.

\section{Conclusão}

Habermas, a meu ver, nos dois períodos do seu desenvolvimento intelectual, para remeter tal crítica, tão radical e pretensiosamente definitiva contra o filósofo do martelo, primeiramente deveria ter explorado mais as possibilidades de sua filosofia ou pelo menos ter se aprofundado um pouco mais nos

23 O apoio para Habermas, nesse ponto, é o primeiro capitulo do livro de Heidegger, Nietzsche I, intitulado "A vontade de potência como Arte". 
textos da época da transvaloração. ${ }^{24}$ Mas, essa não é a estratégia de sua investigação ao analisar a filosofia nietzschiana, pois Nietzsche não é um bom aliado para quem prima por um discurso emancipatório, que possibilite uma interação racional entre os homens, a sua filosofia é desagregadora e crítica de todo discurso com pretensões de universalidade e, também, de plausibilidade, desse modo, deve ser abandonado e afugentado dos limites da razão.

A 'teoria' do perspectivismo elaborada na última fase da obra de Nietzsche, no período da transvaloração, fornece respostas a esse tipo de objeção feita por Habermas. Se a posição cética de Nietzsche em relação ao conhecimento e à verdade o lança numa contradição pragmática, então como podemos defendê-lo? Não é nada simples tal tarefa, para isso, recorreremos à seguinte argumentação: se Nietzsche nega a reflexão como instrumento do conhecimento, então em última instância nega a verdade. Desse modo, podemos afirmar que ele é detentor da máxima cética de que 'não existe a verdade', quando esta proposição é enunciada, tem a pretensão de ser verdadeira e, assim, acaba se auto-refutando, lançando-se numa contradição pragmática. Todavia, se recorrermos à doutrina do perspectivismo, na qual Nietzsche afirma que "não existe a verdade, mas tão somente interpretação", ${ }^{25}$ a princípio, tal relativismo parece ter lhe isentado das acusações habermasianas. Porém, não é bem assim, pois quem defende o relativismo, também tem pretensão de verdade e logo não está isento de tais críticas. Mas se formos persistentes e recorrermos ao Assim Falou Zaratustra (AFZ), obra inserida na última fase da produção intelectual de Nietzsche, talvez encontremos uma solução ou pelo menos uma possibilidade de defesa. Sabemos que a obra AFZ é um livro filosófico-literário. Paul Janz classificou-a de poema didático, ${ }^{26}$ então por que Nietzsche a escolheu para ser o porta-

24 É considerado pelos interpretes de Nietzsche a fase da transvaloração, a última fase, aquela que começa com Assim Falou Zaratustra (1883) até seu últimos escritos.

25 Essa idéia é bastante desenvolvida por Nietzsche na última fase de sua obra, sobretudo em Para Além de Bem e Mal (PABM), mais especificamente no parágrafo 22. Cf. também (Nietzsche, 1988, p.315, v.XII).

26 Cf. Janz, 1981. Todavia, essa designação já era corrente e, dessa forma, o AFZ foi chamado de "romance de formação", o qual tem como característica, a dramatização de um percurso do desconhecido para um âmbito conhecido. Esse estilo, a partir da influência de Rousseau, se desenvolveu na Alemanha, onde recebeu sua forma magistral no Werter e no Wilhelm Meister, de Goethe, e no Hipérion e no Empédocles, de Hölderlin. De modo análogo, foi chamado também de poema didático por alguns. Erwin Rohde, um dos mais próximos amigos de Nietzsche, assim designa a obra em uma carta de 22 de dezembro 1883: "O teu Zaratustra tem me causado uma impressão mais agradável do que os teus outros últimos escritos. (...) !Te felicito por essa forma mais livre de expressar tuas idéias (...) na forma de um poema didático....". O jovem Nietzsche tinha um grande interesse por esse estilo, tanto na versão moderna experimentada por Goethe e Hölderlin quanto na versão antiga de Hesíodo (Os Trabalhos e os Dias) e Parmênides. O "poema didático" e o "romance de formação" são tomados como o mesmo estilo, sendo que um se desenvolve em prosa e o outro em poema ou em poema em prosa. 
voz de sua filosofia, a ponto de dizer na obra autobiográfica, $E H$, que essa é a sua principal obra? AFZ tem a seu favor, justo o que o dificulta de ser considerado uma obra rigorosa, o estilo estético-poético. Nietzsche com o AFZ queria elaborar um saber estético conforme o dos gregos do período trágico, onde não havia uma unidade do conhecimento e da moral - depois inaugurada pela filosofia socrática e sistematizada por Platão e Aristóteles. Porém, apenas o recurso estético não é suficiente para isentar o autor do AFZ das duras críticas de Habermas, pois esse, em DFM, mostra que a saída estética para resolver o problema do conhecimento ou dos limites da razão moderna, já havia sido apresentada pelo romantismo. Para Habermas, Nietzsche apenas radicalizou a posição dos românticos, que após a queda da unidade que a religião garantia, viam no mito, como os gregos, a unidade do todo. A radicalização de Nietzsche, segundo Habermas - como vimos acima - está em não aceitar as posições messiânicas do romantismo, por exemplo, a adotada por Hölderlin.

A singularidade da argumentação de Nietzsche é que, nele, a formação filosófica dos conceitos que visam à verdade, é precedida de uma criação artística de metáforas, onde a busca abstrata da verdade é sem importância e em que a estética ocupa o primeiro plano. Dessa forma, torna-se, a elaboração do AFZ é a maior prova da probidade intelectual de Nietzsche, pois expressou numa obra de ficção o seu saber. Se o nosso aparato categorial é criador de ficções e se a nossa linguagem está a serviço da ilusão, como afirma Nietzsche, então AFZ está em consonância com essas exigências. A grande distinção que se pode estabelecer entre o saber trágico e o saber racional é que o primeiro sabe-se como criador da ilusão e o outro, por não se reconhecer como um produto da ilusão, a elege como o inimigo que deve ser combatido. AFZ é então a maior expressão em Nietzsche da sabedoria criadora que transforma o agir:

$\mathrm{E}$ a isso que haveis dado o nome de mundo, isso deve ser criado primeiro por vós: é isto o que a vossa razão, vossa imagem, vossa vontade, vosso amor devem tornar-se! E, na verdade, para vossa bem-aventurança, homens do conhecimento! (...) Criar - essa é a grande redenção do sofrimento, é o que torna a vida mais leve. Mas para que o criador exista são necessários o sofrimento e muitas transformações. (Nietzsche, 1988, p.110, v.IV)

JULIÃO, José Nicolao. Nietzsche's pragmatism and its aesthetic unfolding according to Habermas. Trans/Form/Ação, (São Paulo), v.31(1), 2008. p.153-175.

- ABSTRACT: This article intends to reconstitute the critical interpretation argumet of Habermas about the nietzschiane philosophy, focung a postface written in 1968, to a collection of texts by Nietzsche about knowledge theory. Our intention is to 
present the gênesis of interpretation, forteen years later, in the DFM (1982), where Nietzsche is appointed, by Habermas, as turnig point (Drehscheibe) of modernity, that bred, on this way "an irracional speech metaphysically defaced", basis of the post-modernity. However, as the postface is contemporary to the work, CI (1968), in which there is a chapter dedicated to Nietzsche, that complements the postface to muck, we decided to use this material to help our interpretation.

- KEYWORDS: Knowledge, modernity, post-modernity, interpretation.

\section{Referências bibliográficas}

ABEL, G. Verdade e Interpretação. Trad. de Clademir Luís Araldi. Cadernos Nietzsche, São Paulo: EDUSP, p.15-32, n.12, 2002.

ADORNO, T.W. \& HOKHEIMER, M. Dialética do Esclarecimento. Trad. de Antônio Guido de Almeida. Rio de Janeiro: Jorge Zahar Editor, 1985.

COURTINE, Jean-François. A Tragédia e o Tempo da História. Trad. Heloisa B. S. Rocha. Rio de Janeiro: Editora 34, 2006.

DANTO, Arthur. Nietzsche as Philosopher. Nova York: Macmillan, 1965.

FREITAG, Barbara; ROUANET, Sérgio. In: Textos escolhidos de Habermas. São Paulo: Ática, 1980.

FRÜCHTL, J. Radikalität und Konsequenz in der Wahrheitstheorie Nietzsche als Herausforderung für Adorno und Habermas. Nietzsche Studien. Berlim, p.431-61, B. 19, 1990.

GIACOIA, O. Nietzsche e a Modernidade segundo Habermas. Idéias. Campinas, jul./ dez., p.5-38, n.2, 1994.

HABERMAS, J. F. Nietzsche, Erkenntnistheoretische Schriften. Frankfurt: Suhrkamp, 1968a.

HABERMAS, J. Erkenntnis und Interesse. Frankfurt: Suhrkamp, 1968b.

. Der Philosophiche Diskurs der Moderne. Frankfurt: Suhrkamp, 1985.

Passado como Futuro. Rio de Janeiro: Tempo Brasileiro, 1993.

Nachmetaphysisches Denken. Frankfurt: Suhrkamp, 1992.

JANZ, P.C. Nietzsche, Biographie. In: 3 B. München: Carl Hanser Verlag, 1978.

MACCARTHY, T. The Critical Theory of Jürgen Habermas. Cambridge: MIT Press, 1978.

NIETZSCHE, Friedrich. Kritische Studienausgabe. 15 B. - Herausgegeben von G. Colli und M. Montinari. Berlin/New York: dtv/de Gruyter, 1988.

Sämtliche Briefe. Kritische Studienausgabe. 8 B. - Herausgegeben von

G. Colli und M. Montinari. Berlin/New York: dtv/de Gruyter, 1986.

Werke in 3 Bänden, Schlechta. 3.ed. München, 1962.

Obras Incompletas. Trad. de Rubens Rodrigues Torres. In: Col. Os Pensadores. São Paulo: Abril Cultural, 1983.

SCHNÄDELBACH, H. Filosofia en Alemania (1831-1933). Madrid: Cátedras, 1991. 